\title{
Electrocardiographic profile of guinea pig heart submitted to Ginkgo biloba extract and its terpenoids
}

\author{
SANTOS, A.C.O.; SOUZA, J.A.S.; CONDE-GARCIA, E.A.; SOUZA, A.A.; MENEZES-FILHO, J.E.R.; OLIVEIRA, \\ E.D.; VASCONCELOS, C.M.L.* \\ Laboratório de Biofísica do Coração, Departamento de Fisiologia Centro de Ciências Biológicas e da Saúde, \\ Universidade Federal de Sergipe, São Cristóvão, Sergipe, Brazil. ${ }^{*}$ Carla Vasconcelos, PhD, Cidade Universitária \\ Prof. "José Aloísio de Campos", Av. Marechal Rondon, s/n, Jardim Rosa Elze, CEP 49.100-000, São Cristóvão, Sergipe, Brasil. \\ Tel.: +55 79 21056642, E-mail addresses: carlamlv@ufs.br, carlamlv@hotmail.com
}

\begin{abstract}
Electrocardiographic effects produced by Ginkgo biloba extract (EGb) and by ginkgolides $A(G A)$ and $B(G B)$, and bilobalide (BB) were investigated in guinea pig heart mounted in Langendorff apparatus (Tyrode, $34 \pm 0.1{ }^{\circ} \mathrm{C}, 95 \% \mathrm{O}_{2}, 5 \% \mathrm{CO}_{2}$ ). Electrocardiographic parameters were evaluated in the conditions: 1) control with Tyrode and DMSO, 2) EGb $(n=4)$, $\mathrm{GA}(\mathrm{n}=5), \mathrm{GB}(\mathrm{n}=5)$ or $\mathrm{BB}(\mathrm{n}=6)$, and 3$)$ washout. The results showed that 0.1 and $1.0 \mathrm{mg} / \mathrm{ml}$ of EGb do not change the electrocardiographic parameters. However, $10 \mathrm{mg} / \mathrm{ml}$ of EGb increased the PR interval (PRi) at 21\% ( $p<0.001)$. This increase was also observed for $50 \mathrm{mM} \mathrm{GA}(20 \%$, $p<0.001)$ and $70 \mathrm{mM} \mathrm{BB}(13 \%, \mathrm{p}<0.001)$, which indicates $\mathrm{Ca}^{2+}$ channel block. However, the $50 \mathrm{mM}$ GB reduced the PRi at $11 \%(p<0.001)$. The GA $(23 \%, p<0.001), G B(16 \%, p<0.001)$, and BB $(40 \%, p<0.001)$ reduced the QT interval $(\mathrm{QTi})$, which suggests the activation of the potassium channel. However, EGb increased QTi (6\%, p<0.001). The EGb $(28 \%, p<0.05)$ and GB $(13 \%, p<0.05)$ reduced the heart rate. Atrioventricular (AV) block was observed with EGb, $\mathrm{GA}$, and $\mathrm{BB}$. We can conclude that EGb and its terpenoids alter the ECG parameters inducing AV block, which indicates possible arrhythmogenic potential.
\end{abstract}

Keywords: Ginkgo biloba, ginkgolide A, ginkgolide B, bilobalide, heart.

\begin{abstract}
RESUMO. Perfil eletrocardiográfico do coração de cobaia submetido ao extrato de Ginkgo biloba e seus terpenóides. Os efeitos eletrocardiográficos produzidos pelo extrato de Ginkgo biloba (EGb) e gingkolídeos A (GA) e B (GB), e bilobalide (BB) foram investigados em coração de cobaia montado sistema de Langendorff (Tyrode, $34 \pm 0.1{ }^{\circ} \mathrm{C}, 95 \% \mathrm{O}_{2}, 5 \% \mathrm{CO}_{2}$ ). Os parâmetros do ECG foram avaliados nas condições: 1) Tyrode e DMSO, 2) EGb ( $n=4), G A(n=5), G B(n=5)$ ou BB ( $n=6$ ) diluídos em DMSO e 3) washout. Os resultados demonstram que 0,1 e 1,0 mg/ $\mathrm{mL}$ de $\mathrm{EGb}$ não alteraram os parâmetros eletrocardiográficos. Entretanto, $10 \mathrm{mg} / \mathrm{ml}$ de EGb aumentaram o intervalo PR (PRi) em 21\% ( $p<0.001)$. Esse aumento também foi observado com GA a $50 \mu \mathrm{M}(20 \%, \mathrm{p}<0,001)$ e BB a $70 \mathrm{mM}(13 \%, \mathrm{p}<0,001)$ indicando bloqueio de canais de cálcio. Por outro lado, GB reduziu o PRi $(11 \%, p<0,001)$. O intervalo QT (QTi) foi reduzido por GA $(23 \%, p<0,001), G B(16 \%, p<0,001)$ e BB $(40 \%, p<0.001)$ sugerindo uma ativação de canais de potássio. Entretanto, EGb aumentou o QTi $(6 \%, p<0.001)$. A frequência cardíaca foi reduzida por $\mathrm{EGb}(28 \%$, $\mathrm{p}<0.05)$ e $\mathrm{GB}(13 \%, \mathrm{p}<0.05)$. Bloqueios átrio-ventriculares $(\mathrm{BAV})$ foram observados com EGb, GA e BB. Podemos concluir que EGb e os terpenos alteram parâmetros eletrocardiográficos induzindo BAV e demonstrando possível potencial arritmogênico.
\end{abstract}

Palavras-chave: Ginkgo biloba, ginkgolídeo A, ginkgolídeo B, bilobalide, coração.

\section{INTRODUCTION}

Since long time the Chinese folk medicine uses Ginkgo biloba extracts (Chen et al, 2005). This plant continues to be largely employed and studied. The standard extract of Ginkgo biloba leaf (EGb761) contains $24 \%$ of flavonoids glycosides (quercetin, kaempferol, isorhamnetin, etc.), $6 \%$ terpenoids (3.1\% are ginkgolides $\mathrm{A}, \mathrm{B}, \mathrm{C}$, and $\mathrm{J}$ and $2.9 \%$ is bilobalide), and $5-10 \%$ organic acids (Cheng, 1996; Huh \& Staba, 1992; Kressmann et al., 2002; Qi et al., 2004). 
Ginkgo biloba may be of great value in cases of age-related mental dysfunction (Kleijnen \& Knipschild, 1992; Zhang et al., 2000; Maclennan et al., 2002) including senility, dementia (Le Bars et al., 1997), and diminished memory (Keenedy et al., 2000). Numerous preclinical studies have shown the neuroprotective effects of the standard extract EGb761 and support the notion that it may be effective in the treatment and prevention of neurodegenerative disorders such as Alzheimer's disease $^{2}$. Anti-oxidative, anti-apoptosis, antiinflammation, protection against mitochondrial dysfunction, amyloidogenesis and amyloid beta peptide $(A \beta)$ aggregation, ion homeostasis, modulation of phosphorylation of tau protein and even induction of growth factors are possible mechanisms of action (Cheng, 1996).

Several authors reported that therapeutic properties presented by EGb seems to be associated to its vasorelaxant action involving activation of the cellular nitric oxide pathway, antagonism of the platelet activating factor (PAF), anti-oxidant effect (Diamond et al., 2000), and/or the inhibition of $\mathrm{Ca}^{2+}$ influx through the L-type $\mathrm{Ca}^{2+}$ channel (Satoh \& Nishida, 2004). Ginkgolide B (GB) could antagonize PAF receptors, preventing thus the ischemical damage of myocardial cells (Keeskemeti \& Balogh, 2001). Experimental results obtained with $\mathrm{GB}$ revealed that it prevented cardiac arrhythmias induced by the ischemiareperfusion protocol (Wainwright et al, 1989; Koltai et al., 1989).

Was verified that EGb (120 mg) administrated during 7 days to healthy volunteers did not modify ECG parameters neither the heart rate, nor systolic or the diastolic blood pressures ${ }^{16}$. However, it was reported a case of a patient that used $E G b$ and presented ventricular arrhythmias that only disappeared after discontinuing $E G b$ (Cianfrocca et al., 2002). EGb and bilobalide (BB), used at high concentrations, usually produced cardiac arrhythmias and/or sinus arrest in rats (Satoh \& Nishida, 2004). Recently, was reported that $\mathrm{EGb}$ in high concentrations reduced the contraction force in rat heart and decreased of mitochondrial respiratory function (Baliutyte et al., 2012). However, the authors don't elucidate what was the compound bioactive responsible for this effect. Such findings encourage us to study the effect of $E G b$ and some of its majoritaria terpenoids (ginkgolide A, ginkgolide B and bilobalide) on the eletrocardiographic parameters in guinea pig isolated heart, which can be responsible of the EGb effect.

\section{MATERIALS AND METHODS}

\section{Animals}

The experiments were carried out on the guinea pig (Cavia porcellus) heart of male adult animals (300 to $500 \mathrm{~g}$ ) of both genders. Animals had free access to food and water Ad libtum and were kept at room temperature $\left(27 \pm 3{ }^{\circ} \mathrm{C}\right)$ with 12 $\mathrm{h}$ of light-dark cycles. The research project was previously approved by the Ethical Animal Research Committee of the Federal University of Sergipe, according to the protocol \#33/07.

\section{Drugs}

Ginkgo biloba extract (EGb) used was a standardized extract obtained from leaves, containing $25.2 \%$ flavonoids glycosides and $3.5 \%$ terpene lactones, was provided by Fármacos (Sergipe) from Hong Kong (China). Ginkgolides A and B, as well as bilobalide were purchased from Sigma-Aldrich (St. Louis, MO, USA). $\mathrm{NaCl}, \mathrm{KCl}, \mathrm{MgCl}_{2}, \mathrm{NaHCO}_{3}$, $\mathrm{CaCl}_{2}$, Glucose, $\mathrm{NaH}_{2} \mathrm{PO}_{4}$ were from Merck S.A. Indústrias Químicas (Rio de Janeiro, Brazil), dimethyl sulfoxide (DMSO) from Vetec Química Fina LTDA (Rio de Janeiro, Brazil), carbogen mixture from White Martins Gases Industriais S.A. (São Paulo, Brazil), and heparin (Liquemine) from Roche Laboratories (São Paulo, SP, Brazil).

\section{Isolated heart experimental assembly}

Guinea pigs were sacrificed by decapitation 30 minutes after administration of heparin (1000 I.U., i.p.). Their hearts were removed, mounted on a Langendorff apparatus of constant flow (Döring, 1990), and perfused with Tyrode solution (mM): $\mathrm{NaCl}$ 120.0, $\mathrm{KCl} 2.7, \mathrm{MgCl}_{2} 0.9, \mathrm{NaHCO}_{3} 11.9, \mathrm{CaCl}_{2} 1.37$, Glucose 5.5, $\mathrm{NaH}_{2} \mathrm{PO}_{4}$ 0.4. This solution was warmed up to $34 \pm 0.1{ }^{\circ} \mathrm{C}$ (Haake F3, Berlin, Germany), oxygenated and buffered by carbogen mixture (95 $\% \mathrm{O}_{2}$ and $5 \% \mathrm{CO}_{2}$ ). Tyrode was thoroughly filtered (cellulose acetate membrane, mesh $0.45 \mu \mathrm{m}$ ) before using to avoid vascular microembolia (Harrison \& Raymond, 1951). The heart, mounted into the organ chamber, was electrically driven by suprathreshold pulses of DC current, which were generated isolated from the ground (Anapulse Stimulator 302-T, WPI Instruments, Inc., 60 Fitch Street, POX 3110, New Haven, Connecticut 06515, USA; Digitimer D4030, Digitimer DS2, Digitimer Limited, Tewin Road, Welwyn Garden City, Hertfordshire, England). The electrical stimuli were delivered through a pair of stainless steel electrodes connected to the right atrium appendage. The whole preparation was maintained immersed in Tyrode $(50 \mathrm{ml})$ in which three electrodes $(\mathrm{Ag} / \mathrm{AgCl} / \mathrm{NaCl}, 1 \mathrm{M})$ were placed for sensing the heart electrical signal. This allowed the ECG to be recorded. ECG signals were amplified 
(HP8811B, HP7754A, HP7754B, Hewlett-Packard, Chicago, Illinois, USA) and stored in a computer for off-line processing (DI-205, DI-400, Windaq Pro, Dataq, 241 Springside Drive Suite 200, Akron, Ohio 44 333, USA). Biological preparations were stabilized for 30 minutes before beginning the experimental maneuvers.

\section{Electrocardiographic parameters and heart rate measurements}

The following electrocardiographic parameters were measured: PR interval (PRi), QT interval (QTi), and QRS complex duration (QRS). They were evaluated during the control situation (Tyrode + DMSO $0.5 \%$ ), test (EGb, GA, GB or BB diluted in DMSO $0.5 \%$ ), and washout (Tyrode + DMSO $0.5 \%$ ). The effect Ginkgo biloba constituents on the heart rate was studied on isolated heart allowed to beat spontaneously. To accomplish that, successive $R-R$ intervals were determined during control, test, and washout (Calculate and WindaqEx softwares from Dataq, Akron, Ohio, USA).

\section{Statistical analysis}

Data were analyzed by using ANOVA one-way followed by the 'post hoc' test of Tukey. Differences were significant when $p<0.05$. Results are presented as mean \pm standard deviation.

\section{RESULTS}

The electrocardiographic (ECG) changes promoted by EGb $(10 \mathrm{mg} / \mathrm{ml}), \mathrm{GA}(50 \mu \mathrm{M}), \mathrm{GB}$ $(70 \mu \mathrm{M})$, and $\mathrm{BB}(70 \mu \mathrm{M})$ on the PR interval (PRi) are illustrated in Fig. 1A. PRi is measured from the beginning of the $P$ wave to beginning of the QRS complex and represent the time conduction of electrical impulse through atrioventricular node (AV node) (Azevedo, 1999). We results revealed that slow concentration of EGb $(0.1$ and $1.0 \mathrm{mg} / \mathrm{ml})$ not evoked significant alteration on the ECG profile (data not shown). However, $10 \mathrm{mg} / \mathrm{ml}$ EGb was able to alter ECG parameters increasing significantly the PRi at $21 \pm 2.0 \%(p<0.001)$. Furthermore, we also verified that of terpenoids tested only GA $(20 \pm 5.0$ $\%, p<0.001)$ and BB $(13 \pm 0.39 \%, p<0.001)$ were able to increased this interval. On the other hand, the opposite was observed for GB that slightly decreased PRi at $6.0 \pm 0.39 \%(p<0.001)$. It was found PRi changes promoted by EGb and GB were not restored to the control situation after the washing procedure.

Beyond evaluate PRi also we determined QT interval (QTi) in heart perfused by both EGb or terpenoids. The QTi is a measure of the time between the start of the $Q$ wave and the end of the T wave in the heart's electrical cycle and represents electrical depolarization and repolarization of the left and right ventricles ${ }^{22}$. Ours results showed that the

A

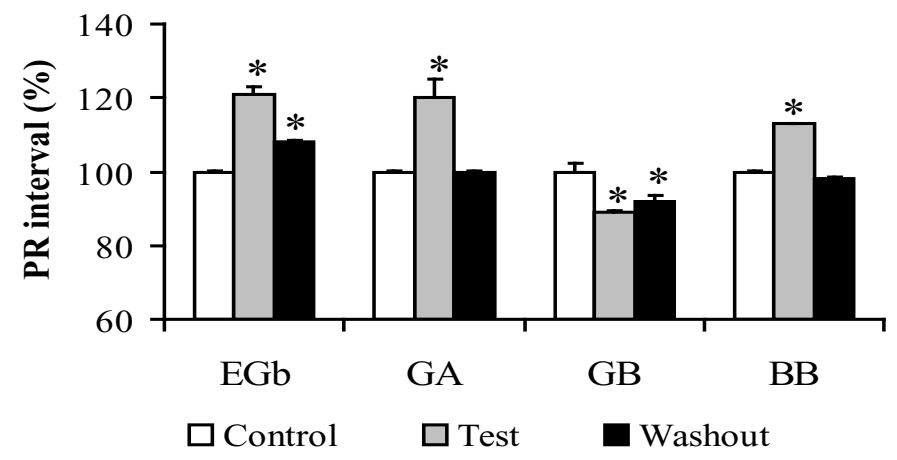

B

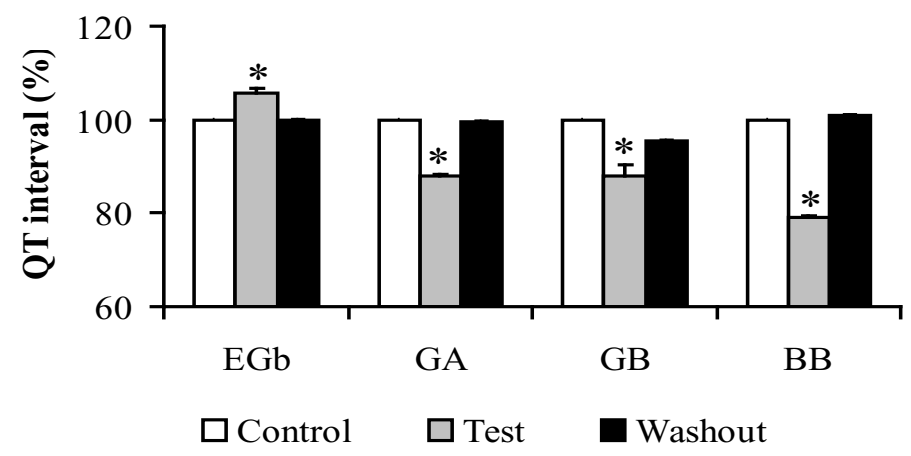

FIGURE 1. Effects of Ginkgo biloba extract ( $E G b, 10 \mathrm{mg} / \mathrm{ml}, \mathrm{n}=4)$ and its constituents $\mathrm{GA}(50 \mathrm{mM}, \mathrm{n}=5)$, GB $(70 \mathrm{mM}, \mathrm{n}=5)$, and BB $(70 \mathrm{mM}, \mathrm{n}=6)$ on the PRi (panel A) and QTi (panel B) of guinea pig isolated heart (34 $\pm 0.1^{\circ} \mathrm{C}$, stimuli: $\left.40 \mathrm{~V}, 1 \mathrm{~ms},{ }^{*} \mathrm{p}<0.001\right)$. 
three terpenoids tested $\mathrm{GA}, \mathrm{GB}$, and $\mathrm{BB}$ reduced the QTi from $209 \pm 0.19 \mathrm{~ms}$ to $161 \pm 2.3 \mathrm{~ms}(23 \%, \mathrm{n}=5$, $\mathrm{p}<0.001), 216 \pm 0.3 \mathrm{~ms}$ to $181 \pm 4.0 \mathrm{~ms}(16 \%, \mathrm{n}=$ $6, p<0.001)$, and from $218 \pm 0.14 \mathrm{~ms}$ to $130 \pm 0.73$ $\mathrm{ms}(40 \%, \mathrm{n}=6, \mathrm{p}<0.001)$, respectively. Moreover, unlike behavior was observed by EGb increasing QTi from $211 \pm 0.11 \mathrm{~ms}$ to $223 \pm 0.9 \mathrm{~ms}(6.0 \%, \mathrm{n}=4, \mathrm{p}$ $<0.001)$. These effects disappeared after removing Gingko biloba constituents from the perfusion fluid (Fig. 1B). QRS complex duration was not altered by EGb or by the terpenoids tested.

Fig. 2A show ECG traces of spontaneous beating heart in control situation (top trace), with EGb (middle trace) and after washout (bottom trace). This results show that EGb induced increased of RR interval from $386 \mathrm{~ms}$ to $500 \mathrm{~ms}$ (29\%). This effect was partially reversible after 20 minutes of washout $(426 \mathrm{~ms})$. Fig. 2B summarizes the heart rate decrease promoted by both EGb and GB from $147 \pm 15 \mathrm{bpm}$ to $106 \pm 22 \mathrm{bpm}(28 \%, \mathrm{n}=4, \mathrm{p}<0.05)$ and from $158 \pm 18 \mathrm{bpm}$ to $138 \pm 21 \mathrm{bpm}(13 \%, \mathrm{n}=5$, $p<0.05)$, respectively. This bradycardia disappeared 20 minutes after initiating the washout. Neither GA nor BB modified the heart rate.

In isolated heart allowed to beat spontaneously, EGb $(10 \mathrm{mg} / \mathrm{ml})$ did not induce arrhythmia, but in preparations electrically driven, it prolonged the PRi leading to a Wenkebach second degree AV block as seen in Fig. 3A. The tracing shows the PRi increasing progressively before appearing a complete AV block. This type of arrhythmia was observed in $40 \%$ of hearts prefunded with EGb. GA (50 mM) on spontaneously beating heart induced the appearance of ventricular extrassystole (Panel B) and also was elicited third degree AVB with a multifocal ventricular rhythm (Panel C). BB evoked a third degree AVB as can be seen in panel $D$ and Wenkebach periods (data not shown). The arrhythmias produced by EGb, GA, and BB disappeared during washout.

\section{DISCUSSION}

Pervious study evidenced that high concentration of Ginkgo biloba extract was able to elicit electrocardiographic changes in rat heart

A

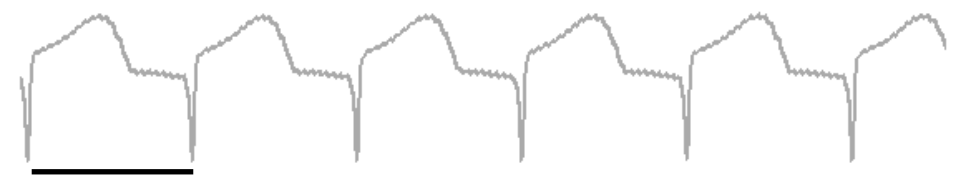

$386 \mathrm{~ms}$

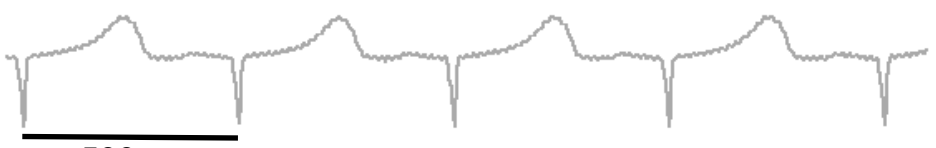

$500 \mathrm{~ms}$

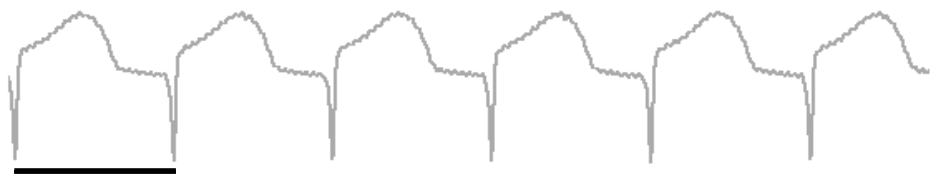

$426 \mathrm{~ms}$

B

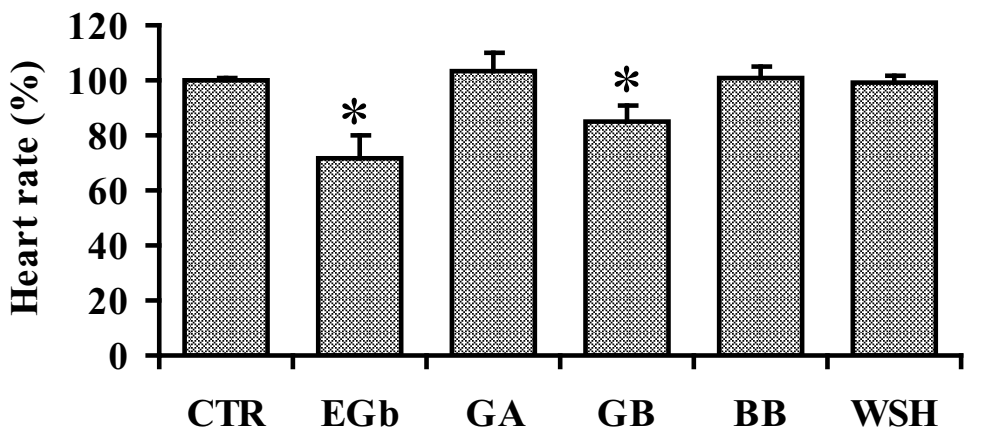

FIGURE 2. Effects of EGb and its terpenoids on the guinea pig heart rate. Panel A shows ECG registers of the heart beating spontaneously in control (top trace), EGb (middle trace) and washout (bottom trace). Panel $B$ represents the summary of the effects of $E G b, G A, G B$, and BB on the guinea pig rate $\left(n=5\right.$, ${ }^{*} p<$ $\left.0.001,34 \pm 0.1^{\circ} \mathrm{C}\right)$. 


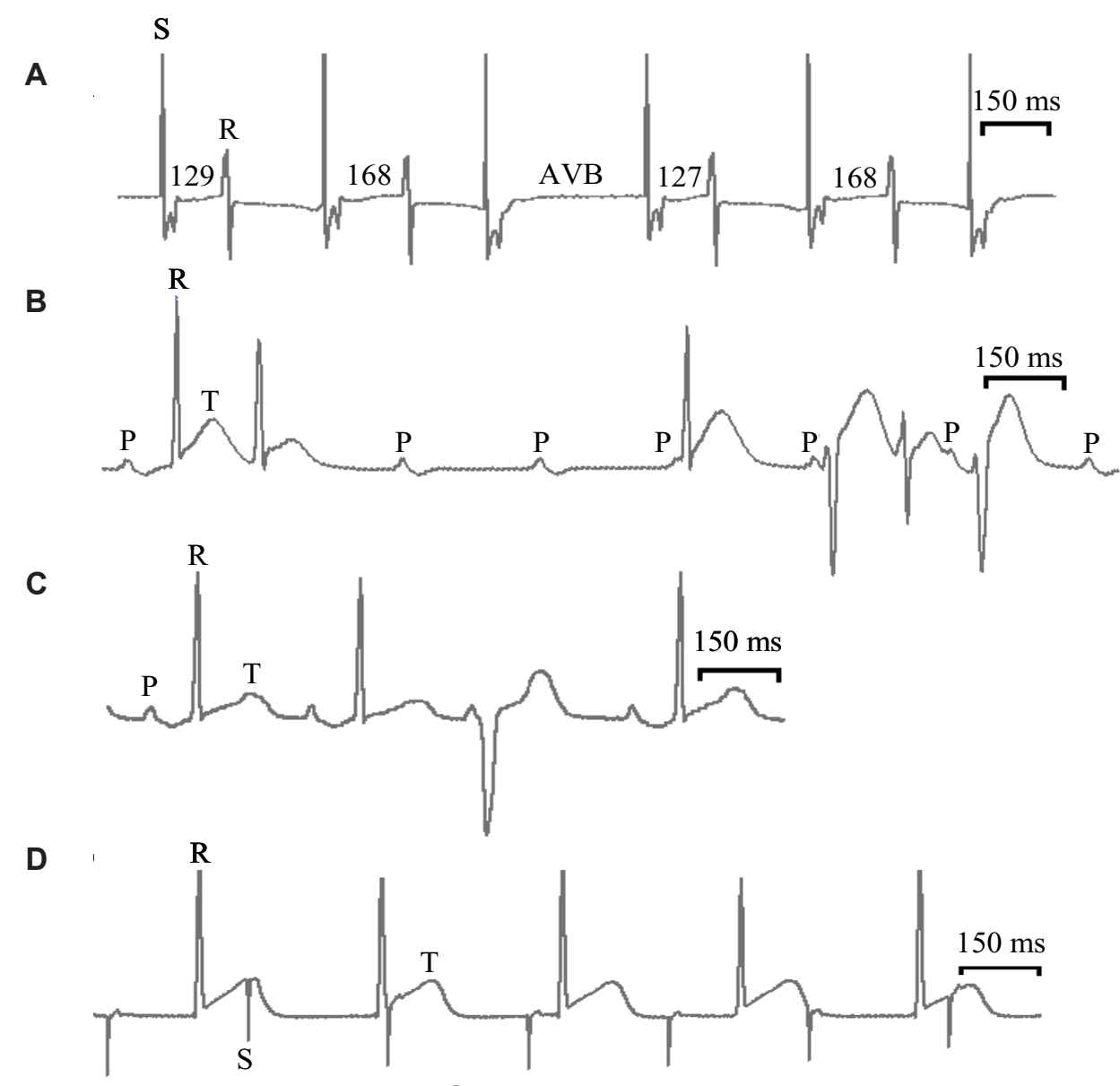

FIGURE 3. Cardiac arrhythmias induced by $E G b$ and its constituents in guinea pig isolated heart. Panel $A$ : EGb $(10 \mathrm{mg} / \mathrm{ml})$ elicited Wenkebach periods characterized by PRi increased following atrioventricular block (AVB). The values in milliseconds relate the measurements of PRi. Third degree AVB with multifocal ventricular rhythm (Panel B) and isolated ventricular extrassystole (Panel C) induced by GA (50 mM) in spontaneously beating (on) guinea pig heart. Panel D: third degree AVB induced by BB $(70 \mathrm{mM})$ on guinea pig isolated heart. S: stimulus artifact; P: $p$ wave; $Q$ : q wave $\left(34 \pm 0.1^{\circ} \mathrm{C}\right)$.

(Baliutyte et al., 2012). However, no correlation was provided between extract effect and its constituents. It is known that the main biological effects of the extract of $G$. biloba are produced by the terpenoids present in its constitution. Furthermore, as EGb is a mixture of its constituents, the final pharmacological response of EGb would be result of complex interaction between the constituents probably by synergism action. Thus, we decided to compare the electrocardiographic effects of the extract with those presented by their major constituents on guinea pig isolated heart.

One of the parameters of ECG measured was PR interval. This interval is the time (in seconds) from the beginning of the $P$ wave (onset of atrial excitation) to the beginning of the QRS complex (onset of ventricular excitation). Is important to emphasize that PRi evaluate principally the electrical conduction through the atrioventricular (AV) node.
We results showed that $E G b$ induced $P R i$ interval. This findings corroborating with other studies (Baliutyte et al., 2012), that observed PRi increased induced by this extract. Furthermore, both GA and $\mathrm{GB}$ also induced PRi increased suggesting that both $\mathrm{GA}$ and $\mathrm{BB}$ can be responsible by enhance PRi induced by GBE. The increased $P R i$, also know as AV block of first degree, produced by EGb, GA, and BB showed that such compounds have a potential arrhythmogenic effect. This phenomenon occurs because they depressed the electrical conduction through the AV node. It's well established that activity of calcium channels in AV nodal cells plays an important role for electrical impulse conduction (Conde-Garcia, 2002). The magnitude of the increase of L-type calcium current $\left(I_{\text {Ca.L }}\right)$ determines the velocity of depolarization during the upstroke of an action potential in nodal cells, and thus the conduction velocity by AV nodal (Schram, 2002). 
Indeed, blockers of $\mathrm{I}_{\mathrm{Ca}, \mathrm{L}}$ can reduce the amplitude of the nodal cell action potential and promote negative dromotropic effect (decrease conduction velocity) inducing AV block.

Several authors showed that EGb $(1 \mathrm{mg} /$ $\mathrm{ml}$ ) markedly inhibited the $I_{\text {Ca.L }}$ in guinea pig and rat ventricular myocytes submitted to a voltage-clamp experiments (Satoh, 2003; Satoh \& Nishida, 2004). The reduction of $I_{\text {ca, }}$ can be responsible for the AV block of first degree induced by EGb observed in our experiments. On the other hand, it's was verified GA (Satoh \& Nishida, 2004), GB (0.1-3 mM), and BB (1 mM) (Satoh, 2003; Satoh \& Nishida, 2004) enhanced the $\mathrm{I}_{\mathrm{ca}, \mathrm{L}}$ and the delayed rectifier $\mathrm{K}^{+}$current $\left(\mathrm{I}_{\mathrm{K}}\right)$. In cardiac muscle, it was evidenced that intracellular calcium increase can promote cellular decoupling by diminish the conductance of nexi (Burt \& Spray, 1988). The ability of terpenoids to block calcium channels has been extensively studied in recent years (Magyar, 2004; Cerqueira et al., 2011).

Several authors use extracts plant at high concentration for studies in vitro and in vivo (Circosta et al., 2005; Menezes et al., 2007). This fact can be justified due the slow percentage of majoritarian compounds present in this extracts. Even at low concentrations, these constituents are extensively studied and present various biological effect (Singh et al., 2010). It's was observed that changes in environmental conditions and other factors can influence in plant metabolism inducing difference in the levels of this majoritarian compound (Satoh, 2005). Was used $1 \mathrm{mg} / \mathrm{ml}$ of Ginkgo biloba extract in isolated ventricular cardiomyocyte submitted to patchclamp technique (Satoh \& Nishida, 2004) and in the present study we used $0.1,1.0$ and $10 \mathrm{mg} / \mathrm{ml}$ because the experiments was carried out in isolated organ. In the present study, $10 \mathrm{mg} / \mathrm{ml}$, this extract contains only approximately $3.5 \%$ of terpenoids of which are $1.8 \%$ of ginkgolides and $1.69 \%$ of bilobalide. In recent study, authors use several concentration of Ginkgo biloba, but not show the concentration of extract in grams (mass unity), difficultly the comparison with our research (Baliutyte et al., 2012).

As noted in our experiments, the QTi was only increased by EGb. This result reflects an increase in the action potential duration (APD) probably by potassium channel block. In fact, it was demonstrated in guinea pig and in rat ventricular myocytes that $E G b$ $(1 \mathrm{mg} / \mathrm{ml}$ ) prolonged the APD (Satoh, 2004; Satoh \& Nishida, 2004). Simultaneously, these authors showed that $\mathrm{EGb}$ markedly inhibits delay rectifying $\mathrm{K}^{+}$ current $\left(I_{K}\right)$ and also the inward rectifying $\mathrm{K}^{+}$current $\left(I_{\mathrm{K} 1}\right)$ what could explain the prolonged QTi observed in our results. Unlike of extract, GA, GB, and BB decreased the QTi. This could be reflecting a shortening of the APD. Satoh \& Nishida (2004) demonstrated in the guinea pig ventricular cardiomyocytes that $\mathrm{GB}(1 \mathrm{mM})$ and $\mathrm{BB}(3 \mathrm{mM})$ were able to shorten the APD and also increased $I_{K}$. We have observed that those terpenoids shorten QTi that could be due to increase of $I_{K}$.
In spite of the GA decrease the QTi, studies performed on the guinea pig ventricular cardiomyocytes showed that GA (1-3 mM) prolonged the APD, a fact that should increase the QTi in the ECG (Satoh \& Nishida, 2004). This finding indicates that the prolonging QTi by EGb can't be attributable to the isolated action of a single terpenoid but to a synergistic action of its constituents which individually have an effect opposite to that shown by the extract.

We results showed that both EGb and GB were able to reduce pacemaker activity of the sinus node. It's was demonstrated that EGb and BB can changes the pacemaking activity (Satoh, 2005). This author reported that EGb $(0.03 \mathrm{mg} / \mathrm{ml})$ and $\mathrm{BB}$ $(0.3 \mathrm{mM})$ promote a negative chronotropic effect. Furthermore, EGb $(0.03 \mathrm{mg} / \mathrm{ml})$ decreased the slope of slow diastolic depolarization (SDD) (action potential phase 4) of sinus nodal cells and depressed their spontaneous activity in a concentration-dependent fashion. Moreover, at high concentration, EGb and BB often cause dysrhythmias and/or a sinus arrest (Satoh \& Nishida, 2004). In sino-atrial nodal cells, submitted to patch-clamp techniques, it's was demonstrated that the following currents were decreased by EGb $(0.03 \mathrm{mg} / \mathrm{ml})$ and BB $(0.3 \mathrm{mM}):$ a) $\mathrm{I}_{\mathrm{Ca}, \mathrm{L}}$; b) $\mathrm{I}_{\mathrm{f}}$, funny current (hyperpolarization-activated inward current); and c) $I_{\mathrm{K}}$. These results indicated that both $E G b$ and $\mathrm{BB}$ can alter the cardiac ionic channel functioning in rat sino-atrial nodal cells (Satoh \& Nishida, 2004).

Our findings showed that in guinea pig isolated heart EGb, GA and BB depress the conduction through atrioventricular node, leading to a several degrees of AVB (1st, 2nd, 3rd degrees). Ours results indicate that these compounds would can have potential arrythmogenic confirming the clinical findings observed in patients making use of extracts of Ginkgo biloba. In addition, Ginkgo biloba effects on mammalian myocardium are due synergic actions of its major constituents.

\section{ACKNOWLEDGMENTS}

The authors wish to thanks to the Federal University of Sergipe, FAPITEC (Edital Universal 07/2008), ELETROBRAS (Centrais Elétricas Brasileiras, Process \#23113.009351/03-67), and CNPq (Process \#478581/2008-4) for financial support.

\section{REFERENCES}

Chen, B.; Caia, J.; Song, L.S.; Wang, X.; Chen, Z. Effects of Ginkgo biloba extract on cation currents in rat ventricular myocytes. Life Sciences, v.76, p.1111-1121, 2005.

Cheng, X. Progress of pharmacological reserch on cardiovascular and cerebral vascular effect of Ginkgo biloba extract and its enlightenmet. Chinese journal of integrated traditional and Western medicine, v.16, 
p.387-389, 1996.

Huh, H.; Staba, E.J. The botany and chemistry of Ginkgo biloba L. Journal of Herbs, Spices \& Medicinal Plants, v.1, p.92-124, 1992.

Kressmann, S.; Muller, W.E.; Blume, H.H. Pharmaceutical quality of different Ginkgo biloba brands. Journal of Pharmacy and Pharmacology, v.54, p.661-669, 2002.

QI, X-Y.; ZHANG, Z-X.; XU, Y-Q. Effects of Ginkgolide B on action potential and calcium, potassium current in guinea pig ventricular myocytes. Acta Pharmacologica Sinica, v.25, p.203-207, 2004.

Kleijnen, J.; Knipschild, P. Ginkgo biloba for cerebral insufficiency. British Journal of Clinical Pharmacology, v.34, p.352-358, 1992.

Zhang, W.R.; Hayashi, T.; Kitagawa, H.; Sasaki, C.; Sakai, K.; Warita, H.; Wang JM, Shiro Y, Uchida M, Abe K. Protective effect of Ginkgo biloba extract on rat brain with transient middle cerebral artery occlusion. Neurological Research, v.22, p.517-521, 2000.

Maclennan, K.M.; Darlington, C.L.; Smith, P.F. The CNS effects of Ginkgo biloba extracts and ginkgolide B. Progress in Neurobiology, v.67, p.235-257, 2002.

Le Bars, P.L.; Katz, M.M.; Berman, N.; Itil, T.M.; Freedman, A.M.; Schatzberg, A.F. A placebo-controlled, double-blind, randomized trial of an extract of Ginkgo biloba for dementia. The journal of the American Medical Association, v.278, p.1327-1332, 1997.

Keenedy, D.O.; Scholey, A.B.; Wesnes, K.A. The dosedependent cognitive effects of acute administration of Ginkgo biloba to healthy young volunteers. Psychopharmacology, v.151, p.416-423, 2000.

Diamond, B.J.; Shiflett, S.C.; Schoenberger, N.E. Ginkgo biloba extract: mechanisms and clinical indications. Archives of physical medicine and rehabilitation, v.81, p.668-678, 2000.

Satoh, H.; Nishida, S. Electropharmacological actions of Ginkgo biloba extract on vascular smooth and heart muscles. Clinica Chimica Acta, v.342, p.13-22, 2004.

Keeskemeti, V.; Balogh, I. Cardiac ultrastructural effect of the platelet-activating factor and its antagonist BN 52021. Experimental and Toxicology Pathology, v.47, p.463-470, 2001.

Wainwright, C.L.; Parratt, J.R.; Bigaud, M. The effect of PAF antagonists on arrhythmias and platelets during acute myocardial ischemia and reperfusion. European Heart Journal, v.10, p.253-243, 1989.

Koltai, M.; Tosaki, A.; Hosford, D.; Barquet, P. Ginkgolide $B$ protects isolated hearts against arrhythmias induced by ischemia but not reperfusion. European Journal of Pharmacology, v.164, p.293-302, 1989.

Kalus, J.S.; Piotrowski, A.A.; Fortier, C.R.; Liu, X.; Kluger, J.; White, C.M. Hemodynamic and electrocardiographic effects of short-term Ginkgo biloba. The Annals of Pharmacotherapy, v.37, p.345-349, 2003.

Cianfrocca, C.; Pelliccia, F.; Auriti, A.; Santini, M. Ginkgo biloba induced frequent ventricular arrhythmia. Italian Heart Journal, v.3, p.689-691, 2002.

Baliutyte, G.; Baniene, R.; Gendviliene, V.; Martisiene, I.; Trumbeckaite, S.; Borutaite, V.; Toleikis, A. Influence of ethanol extract of Ginkgo biloba leaves on the isolated rat heart work and mitochondria functions. Journal of Cardiovascular Pharmacology, v.59, p.450-457, 2012.

Döring, H.J. The isolated perfused heart according to Langendorff technique - Function - Application. Physiologia Bohemoslovaca, v.39, p.481-505, 1990.

Harrison, G.E.; Raymond, W.H.A. Preparation of clean chemical solutions. British Medical Journal, v.2, p.930-932, 1951.

Azevedo, D.F. Iniciação a eletrocardiografia. Ed. ArtMed, 1999.

Conde-Garcia, E.A. Biofísica. Ed. Savier, Rio de Janeiro, 2002.

Schram, G.; Pourrier, M.; Melnyk, P.; Nattel, S. Differential distribution of cardiac ion channels as a basis for regional specialization in electrical function. Circulation Research, v.90, p.939-950, 2002.

Satoh, H. Effects of Ginkgo biloba extract and Bilobalide, a main constituent, on the ionic currents in guinea pig ventricular cardiomyocytes. Progress in drug research, v.53, p.407-413, 2003.

Burt, J.M.; Spray, D.C. Inotropic agents modulate gap junctional conductance between cardiac myocytes. American Journal Physiology, v.254, p.1206-1210, 1988.

Magyar, J.; Szentandrassy, N.; Banyaz, T.; Fulop, L.; Varro, A.; Nanasi, P.P. Effects of terpenoid derivatives on calcium current in canine and human ventricular cardiomyocytes. European Journal of Pharmacology,v.487, p.29-36, 2004.

Cerqueira, S.V.S.; Gondim, A.N.S.; Romam-campos, D.; Cruz, J.S.; Passos, A.G.S.; Lauton-santos, S.; Lara, A.; Guatimosim, S.; Conde-Garcia, E.A.; Oliveira, E.D.; Vasconcelos, C.M.L. R-(+)-pulegone impairs $\mathrm{Ca}^{2+}$ homeostasis and causes negative inotropism in mammalian myocardium. European Journal of Pharmacology, v.672, p.135-142, 2011.

Circosta, C.; De Pasquale, R.; Occhiuto, F. Cardiovascular effects of the aqueous extract of Gynostemma pentaphyllum Makino. Phytomedicine, v.2, p.638-664, 2005.

Menezes, I.A.C.; Moreira, I.J.A.; Carvalho, A.A.; Antoniolli, A.R.; Santos, M.R.V. Cardiovascular effects of the aqueous extract from Caesalpinia ferrea: Involvement of ATP-sensitive potassium channels. Vascular Pharmacology, v.47, p.41-47, 2007.

Singh, R.D.; Gopichand, Meena, R.L.; Sharma, B.; Singh, B.; Kaul, V.K.; Ahuja, P.S. Seasonal variation of bioactive components in Valeriana jatamansi from Himachal Pradesh, India. Industrial Crops and Products, v.32, p.292-296, 2010.

Satoh, H. Comparative electropharmacological actions of some constituents from Ginkgo biloba extract in guinea-pig ventricular cardiomyocytes. Evidence Based Complementary and Alternative Medicine, v.1, p.277-284, 2004.

Satoh, H. Suppression of pacemaker activity by Ginkgo biloba extract and its main constituent, bilobalide in rat sino-atrial nodal cells. Life Sciences, v.78, p.67-73, 2005. 